\title{
Hrvatsko nazivlje molekularne i stanične biologije
}

\author{
Petra Korać ${ }^{1}$, Ana Vraneša ${ }^{2}$, Bernardina Petrović, ${ }^{3}$, Mirjana Pavlica ${ }^{1}$ \\ ${ }^{1}$ Zavod za molekularnu biologiju, Biološki odsjek, Prirodoslovno-matematički fakultet, Sveučilište u Zagrebu, Horvatovac \\ 102a, 10000 Zagreb, Hrvatska \\ mirjana.pavlica@biol.pmf.hr \\ 2 Ministarstvo kulture, Runjaninova 2, 10000 Zagreb, Hrvatska \\ ${ }^{3}$ Katedra za hrvatski standardni jezik, Odsjek za kroatistiku, Filozofski fakultet, Sveučilište u Zagrebu, Ivana Lučića 3, 10000 \\ Zagreb, Hrvatska
}

\begin{abstract}
SAŽETAK
Nazivlje mnogih struka često se razvija neovisno o pravilima hrvatskoga jezika, posebice ako je riječ o mladim znanostima koje nastaju i razvijaju se na engleskome jeziku. Jedan je od takvih primjera leksik molekularne biologije. lako je razvoj ovoga područja u Hrvatskoj započeo 1960-ih godina na Sveučilištu u Zagrebu i Institutu Ruđer Bošković, da bi 1984. godine bio pokrenut i studij molekularne biologije na Biološkome odsjeku Prirodoslovno-matematičkoga fakulteta, a 1989. osnovan Zavod za molekularnu biologiju pri istome odsjeku, sve donedavno nije postojao usustavljen način prilagodbe strukovnoga nazivlja. Budući da je molekularna biologija sve češće zastupljena u informativnim medijima zbog sve većega značenja rezultata istraživanja ovoga područja u kontekstu svakodnevnoga života, na Zavodu za molekularnu biologiju Prirodoslovno-matematičkoga fakulteta započeta su dva biološko-jezična projekta. Prvi je projekt prijevod rječnika molekularne i stanične biologije koji sadržava više od 12000 unosa, čiji je cilj usustavljivanje hrvatskoga leksika područja kao rezultat suradnje jezikoslovaca i biologa. Drugi projekt - „Genetikon“ - financirala je Hrvatska zaklada za znanost putem projekta "Struna“, a on obuhvaća genetički leksik omogućujući da na jednome mjestu budu okupljeni najvažniji pojmovi i sustavno razrađeno hrvatsko nazivlje. $U$ ovome radu dajemo kratak pregled razvoja jezika struke s posebnim naglaskom na šest osnovnih naputaka kojima nastojimo pridonijeti razvoju leksika genetike i stanične $i$ molekularne biologije.
\end{abstract}

Ključne riječi: nazivlje struke; leksik molekularne biologije, genetički leksik; biološko-jezični projekti; usutavljivanje leksika

\section{UVOD}

Hrvatski standardni jezik, kao i svaki živući jezik, prolazi kroz razdoblja širenja i rasta, prihvaćanja internacionalizama i stvaranja novih naziva za koje se pokaže potreba proizašla iz društvenih promjena, tehnološkoga razvoja i globalizacije. Kao razumljiva i očekivana pojava, proširenje korpusa standardnoga jezika trebalo bi obuhvaćati osnovne terminološke postavke i pravila koja su osnova hrvatskoga jezika (Hudeček, 2012; Bratanić, 2015). Međutim, u području strukovnoga nazivlja česta je pojava zaobilaženja potrebnih preduvjeta i stvaranje vlastitih termina koji unutar zatvorenih profesionalnih zajednica jednako često prerastaju u žargonizme iako njihovi tvorci toga nisu svjesni.

Početkom usustavljivanja suvremenoga strukovnog nazivlja i njegova usklađivanja sa standardnim hrvatskim jezikom može se smatrati osnivanje baze Struna pri Institutu za hrvatski jezik i jezikoslovlje. lako je ta baza osnovana 2008. godine, otkad je prikupljen velik broj naziva iz različitih područja, sve donedavno biologija je bila nedovoljno zastupljena (Lopac, 2012). Posebno je to bio slučaj s područjem molekularne i stanične biologije. Nazivlje ovih mladih znanosti sve se brže razvija i zbog toga zahtijeva

Korać, P., Vraneša, A., Petrović, B., Pavlica, M. 2018. Hrvatsko nazivlje molekularne i stanične biologije. Educ. biol., 4:69- 
neprestanu i predanu suradnju jezikoslovaca i stručnjaka područja kako bi se na vrijeme usmjerio razvoj jezika i omogućilo znanstvenicima i nastavnicima da predaju i pišu na materinskome jeziku.

\section{Razvoj molekularne biologije i počeci strukovnog nazivlja}

Razvoj molekularne biologije u Hrvatskoj započeo je 1960-ih godina na Sveučilištu u Zagrebu i Institutu Ruđer Bošković. Godine 1984. započet je studij molekularne biologije na Biološkome odsjeku Prirodoslovno-matematičkoga fakulteta, a 1989. osnovan je i Zavod za molekularnu biologiju pri istome odsjeku. Potreba za usustavljivanjem hrvatskoga znanstvenog leksika postajala je sve veća, ali nije bilo službenih, institucionaliziranih interdisciplinarnih aktivnosti koje bi je ispunile. Brz razvoj područja uzrokovao je nekritičko preuzimanje naziva iz većih, utjecajnih jezika, posebno engleskoga. Tomu je pridonijela, a i dalje pridonosi, i činjenica da je znanstvena produkcija područja molekularne biologije većinom na engleskome jeziku, a da stručna terminologija na materinskome jeziku nikada nije usklađena sa standardnojezičnim zakonitostima i terminološkim zahtjevima.

Zanimljivo je da se biologija kao prirodna znanost sve do 1946. godine podučavala i razvijala unutar Filozofskoga fakulteta kao i da je početak oblikovanja znanstvenoga i stručnoga prirodoslovnog nazivlja u Hrvatskoj moguće smjestiti u drugu polovicu 19. stoljeća. Gledajući unatrag, postojali su pokušaji i potencijal suradnje u zajedničkim interesima prirodoslovlja i jezikoslovlja, no društvena zbivanja koja su uslijedila usporila su ili čak zaustavila ta nastojanja.

lako je već tada postojala potreba za pisanjem kvalifikacijskih, znanstvenih i stručnih radova na materinskome jeziku sa svrhom bolje edukacije i primjene rezultata istraživanja u gospodarstvu, ona se do danas manifestirala samo neusklađenim, sporadičnim doprinosima pojedinaca. Jedan od osamljenijih primjera velikoga doprinosa interdisciplinarnomu području razvoja nazivlja biologije jest rad Bogoslava Šuleka (Jonke, 1954). U 19. stoljeću on je objavio „Hrvatsko-njemačko-talijanski rječnik znanstvenoga nazivlja“ (prvi svezak 1874., drugi 1875.) i „Jugoslavenski imenik bilja“ (1879.) (Šulek, 1874-1875). Nakon njega postojali su slični pokušaji pojedinaca, koji su imali znatno manji utjecaj, da bi se s vremenom prorijedili i da bi na kraju područje biologije izgubilo sastavnicu dobro utemeljenoga, sustavnoga i stručnoga razrađivanja strukovnoga nazivlja.

Paralelno s počecima, pa onda i gubitkom temelja strukovnoga nazivlja biologije, razvijalo se i njezino novo područje.

Godine 1866. Gregor Mendel pojašnjava na koji se način nasljeđuju „čestice“ koje vidimo kao svojstva živih bića (svoje otkriće opisao je na njemačkome jeziku, a najčešće se njegov rad prevodi i podučava na engleskome) (Mendel, 1866; Brown, 2017) Friedrich Miescher pak 1869. godine, najvjerojatnije nesvjestan Mendelovih otkrića u svome susjedstvu, prvi put izolira molekulu kiseloga karaktera $\mathrm{s}$ velikim udjelom fosfora za koju nagađa da bi mogla biti važna u procesima koji određuju život (Brown, 2017). Svoja zapažanja i razmišljanja bilježi, baš kao i Mendel, na njemačkome jeziku. Godine 1902. W. S. Sutton izjavljuje kako napokon može skrenuti pozornost na mogućnost da se sparivanje majčinih i očevih kromosoma i njihova kasnija separacija tijekom mejoze može smatrati fizičkom osnovom Mendelovih zakona nasljeđivanja. Na engleskome jeziku (Brown, 2017; Sutton, 1902). Idućih 40-ak godina posvećeno je pitanju koja molekula nosi nasljednu uputu: je li to protein ili DNA? (Brown, 2017). Rasprave i radovi toga razdoblja odvijaju se uglavnom na engleskome jeziku, koji je gotovo nenamjerno postao jezik znanosti i komunikacije znanstvenika na međunarodnoj razini. Godine 1953. na Sveučilištu

Broj 4, prosinac 2018. 
u Oxfordu, u Velikoj Britaniji, kao rezultat rada Rosalind Franklin, Jamesa Cricka i Francisa Watsona, otkrivena je struktura molekule koja nosi nasljednu uputu - poznavanje strukture DNA uzrokuje skokovit razvoj molekularne biologije u internacionalnim razmjerima (Watson, 1953). Grupe Fredericka Sangera i Waltera Gilberta 1977. godine objavljuju načine čitanja redoslijeda baza DNA (Sanger, 1977; Maxam, 1977). Tehnologije sekvenciranja pružaju tako još precizniju analizu nasljedne upute i načina njezine pohrane. Razvija se genetičko inženjerstvo i alati za manipulaciju genomima prokariota i eukariota. Godine 1990. započinje projekt sekvenciranja ljudskoga genoma. Jedanaest godina kasnije objavljen je nacrt ljudskoga genoma, 2003. godine i završni referentni ljudski genom. Nacrt kojim je određena ljudska vrsta rezultat je dviju istraživačkih skupina - kolaboracije pod vodstvom Francisa Collinsa i grupe Craiga Ventera (Brown, 2017; IHGSC, 2001; Venter, 2001). Obje su grupe svoje rezultate objavile u prestižnim časopisima "Nature“ i "Science“ na tada već posve prihvaćenome međunarodnom jeziku znanosti: engleskome (IHGSC, 2001; Venter, 2001). U posljednjih 15-ak godina razvijaju se najnovije generacije tehnologija sekvenciranja, uspostavljaju se alati za precizno prekrajanje genoma i započinju korištenja genskih terapija, no sva ta djelovanja, popratne aktivnosti i njihovi rezultati u hrvatskome jeziku ne pronalaze odgovarajuće terminološko mjesto. Znanstvenici komuniciraju često i puno na engleskome jeziku, a pokušaji usustavljivanja hrvatskoga stručnog standardnog leksika prepušteni su medijima, pojedincima i nekritičkomu usmjeravanju prema krajnostima: pohrvaćivanju internacionalizama do granica nerazumljivosti ili jezično neosnovanomu preuzimanju engleskih naziva koji se doslovno i izravno ubacuju u hrvatske sintagme.

Dodatan problem predstavlja činjenica da je molekularna biologija grana biologije koja je zastupljena ne samo u prirodoslovnome nego i u medicinskome području, čime korelira s višedisciplinarnom terminološkom bazom. lako je razvoj njezina leksika od izuzetnoga značenja za cjelokupni leksički korpus hrvatske znanosti, on se ne događa logičnom, opravdanom i nužnom suradnjom jezikoslovaca i stručnjaka prirodoslovnih znanstvenih disciplina. Dodatna je specifičnost područja molekularne biologije njezina sve češća zastupljenost u informativnim medijima zbog sve većega značenja rezultata istraživanja ovoga područja u kontekstu svakodnevnoga života. Rezultat su neusklađeni nazivi u tekstovima knjiga ovisni o mišljenjima ili jezičnim dojmovima najčešće lektora pojedinih izdavačkih kuća, osobnim lingvističkim stavovima urednika televizijskih i radijskih programa, prevoditelja zaduženih za jezičnu prilagodbu stranih emisija, novinara koji prenose vijesti o znanstvenotehnološkim dostignućima u svrhu izvješćivanja, ali bez osvrtanja na zakonitosti standardnoga jezika i njihovu primjenu u jeziku struke.

\section{Biološko-jezični projekti danas}

Zbog opisane neuređenosti, a imajući na umu da su razvoj i usustavljivanje hrvatskoga leksika molekularne i stanične biologije, $s$ posebnim naglaskom u području genetike, bitna perspektiva očuvanja hrvatskoga jezika, razvoja znanstvene komunikacije i obrazovanja budućih naraštaja stručnjaka navedenih područja na materinskome jeziku, na Zavodu za molekularnu biologiju Biološkoga odsjeka Prirodoslovno-matematičkoga fakulteta Sveučilišta u Zagrebu započeta su dva projekta.

Prvi je projekt prijevod rječnika molekularne i stanične biologije koji sadrži više od 12000 unosa, a čiji je cilj usustavljivanje hrvatskoga leksika područja kao rezultat suradnje jezikoslovaca i biologa (Lackie, 2013). Plan je završiti projekt sredinom tekuće godine nakon četiri godine zajedničkoga rada kroatista

Broj 4, prosinac 2018. 
i molekularnih biologa temeljenoga na pridržavanju pravila hrvatskoga standardnog jezika, terminoloških načela te pouzdanosti i točnosti u kreiranju stručnih naziva. Osim suradnje kroatista i molekularnih biologa, u procesu osmišljavanja terminoloških rješenja, stvaranja novih ili dorađenih naziva za specifične pojmove, korištena je i stručna recenzija kao i profesionalni savjeti liječnika, kemičara i biologa specijaliziranih u drugim područjima biološke znanosti.

Drugi je projekt - „Genetički leksikon“ („Genetikon“) - financirala Hrvatska zaklada za znanost putem projekta Struna. Budući da se genetika zbog sve većega broja istraživanja i utjecaja njihovih rezultata na svakodnevni život sve češće tematizira u različitim medijskih aspektima, projekt sadržajno obuhvaća leksik ovoga područja omogućujući da na jednome mjestu budu okupljeni najvažniji pojmovi i sustavno razrađeno hrvatsko nazivlje. Njime se nastoji olakšati komunikacija i edukacija istraživača u molekularnoj biologiji i medicini, studenata prirodoslovnih i biomedicinskih usmjerenja, stručnih i tehničkih suradnika tih dvaju područja te također pomoći nastavnicima biologije u poučavanju sadržaja molekularne i stanične biologije te genetike. Osim toga želi se pridonijeti i popularizaciji ovoga dijela znanosti jer se vjeruje da bi kreirani korpus mogao zadovoljiti interes i širega čitateljstva te mu služiti kao svojevrstan pojmovnik. Projekt je završio krajem ožujka 2018. godine.

U sklopu projekta „Genetikon“ održane su dvije radionice tijekom veljače 2008. godine na kojima su sudjelovali nastavnici biologije osnovnih i srednjih škola te nastavnici i studenti Biološkoga odsjeka i srodnih ustanova. Na njima se još jednom potvrdilo da postoji velik interes i potreba za smjernicama korištenja usustavljenoga hrvatskog stručnog leksika.

\section{Rezultati suradnje biologa i lingvista}

U časopisu „Educatio Biologiae“ donosimo nekoliko osnovnih zaključaka dugogodišnje suradnje jezikoslovaca i biologa koje stručnjaci i znanstvenici mogu primijeniti u svome svakodnevnom radu bez obzira na područje biologije koje je u njihovu fokusu.

1) Korištenje simbola DNA, RNA i sl.

lako su DNA, RNA i imena ostalih makromolekula često nastajala kao kratice izraza na engleskome jeziku, danas ih smatramo simbolima, simboličkim imenima, pa se ona ne prevode, već se koriste $u$ izvornome obliku. Tako je pojam deoksiribonukleinske kiseline obuhvaćen imenom DNA, a ne DNK, jer je ono nastalo kao kratica engleskoga naziva „deoxyribonucleic acid"; adenozin-trifosfat je ATP, a ne ATF, jer je ime molekule nastalo kraćenjem naziva "adenosin triphosphate“; TBP je kratica dobivena od engleskoga naziva proteina koji se zove „TATA-box binding protein“, a kako je ta kratica zaživjela kao službeno ime proteina, njegov hrvatski naziv „protein koji ima regiju TATA“ neće rezultirati skraćenim imenom PKIRT i sl.

Isto tako, budući da su prvotni akronimi postali službenim, autonomnim imenima, oni se ne „raspisuju“, već se koriste $u$ istome, nepromijenjenome obliku i od njih se nadalje stvaraju izvedenice, npr. RNA i siRNA, tRNA, mRNA, rRNA; DNA i gDNA, cDNA, mtDNA, cpDNA; AMP i cAMP i sl.

2) Apozicija

Engleski jezik zbog svoje analitičke naravi najčešće bilježi navođenje samih naziva i imena bez inkorporiranja apozicijskih elemenata u rečenicu, ali hrvatskomu kao sintetičkomu, flektivnomu jeziku njihovo je dodavanje nužnost (usp. actin binding protein from Dictyostelium : protein koji veže aktin izoliran iz roda Dictyostelium; May promote apoptosis by inducing p53 
phosphorylation : Potiče apoptozu induciranjem fosforilacije proteina p53). Ako se $u$ engleskome ipak navodi apozicija, za nju je rezervirano mjesto iza imena, dok je u hrvatskome ona, podrazumijevajući širi opseg pojma i općenitije značenje, na prvome mjestu (usp. RNA molecule : molekula RNA; RB1 gene : gen RB1).

3) Korištenje spojnice

Spojnica povezuje riječi u polusloženice, a vrlo je korisna u slučajevima kod kojih nije moguće koristiti pridjevni oblik: B-stanice, DNA-polimeraza, X-kromosom i sl.

4) Prednost korištenju domaćih riječi kada je to moguće i kada nude mogućnost tvorbe ostalih oblika kojima predstavljaju korijen: npr. „flagellum“ je bič, a skupina organizama koji su po njemu prepoznatljivi nosi naziv „bičaši“.

5) Preuzimanje naziva iz stranih jezika na temelju njihova porijekla

Nazivi grčkoga i latinskoga jezika imaju prednost pred onima engleskoga, francuskoga, njemačkoga i sl. pa su tako hrvatske riječi "sekvencija“, „referencija“ i „rezonancija“, a ne „sekvenca“, „referenca“ i „rezonanca“.

6) Korištenje pridjeva "genski“, „genetski“, ,genomski“ i „genetički“

$\checkmark$ "Genski“ je pridjev koji je moguće primijeniti kod opisa svojstava koja pripadaju samomu genu, koja se odnose samo na njega - npr. „genska“ sekvencija ili „genska“ mutacija. Često se takav oblik može zamijeniti i jednostavnim korištenjem genitiva: sekvencija ili mutacija gena.

$\checkmark$ "Genetski“ je pridjev koji se može koristiti u dva slučaja - u slučajevima kod kojih se odnosi na genezu, pa je tako ispravno reći „filogenetsko“ stablo, ili u slučajevima kada se koristi za opis rezultata djelovanja gena - npr. ,(mono)genetska“ bolest.

$\checkmark$ "Genomski“ je pridjev koji se rijetko koristi iako je u velikome broju slučajeva i najprecizniji i najtočniji opis onoga što je svojstvo samoga genoma, npr. „genomske“ regije.

$\checkmark$ "Genetički“ je pridjev koji se može koristiti samo onda kada se opisuje grana biologije koja se zove genetika ili rezultat te znanosti: „genetička“ definicija, "genetičko“ inženjerstvo, "genetičko" istraživanje i sl.

\section{ZAKLUČAK}

Zaključno, hrvatski jezik svojim mnogostrukim zakonitostima i pravilima omogućuje neprestano proširenje svoga standardnog korpusa nudeći širok raspon usklađenih mehanizama za izražavanje $\mathrm{i}$ obrazovanje pripadnika različitih struka na materinskome jeziku. Kao i u bilo kojem drugom aspektu biologije, i u strukovnome jeziku ravnoteža je ključna: umjerenost u prevođenju i pohrvaćivanju stranih naziva $s$ jedne strane te $u$ njihovome nekritičkom preuzimanju s druge strane. Jer na kraju ostaje odgovornost: radi sebe i radi šire javnosti znanstvenici bi trebali potpunije i preciznije razumjeti i koristiti ispravan jezik genetike, kao i stanične i molekularne biologije (Judson, 2001).

\section{LITERATURA}

Bratanić, M., Brač, I., Pritchard, B. 2015. Od Šuleka do Schengena - Terminološki, terminografski i prijevodni aspekti jezika struke. Zagreb: Institut za hrvatski jezik i jezikoslovlje.

Brown, T. A. 2017. Genomes 4. New York i London: Garland Science.

Hudeček, L., Mihaljević, M. 2012. Hrvatski terminološki priručnik. Zagreb: Institut za hrvatski jezik i jezikoslovlje.

International Human Genome Sequencing Consortium. 2001. Human Genome. Nature, 409, 813-958.

Jonke, Lj. 1954. „Šulekova briga o hrvatskoj naučnoj terminologiji“. Zbornik Filozofskog fakulteta, knj. 2, 67-81.

Judson, H.F. 2001. Talking about the genome. Nature, 409, 769.

Lackie, J.M. 2013. The Dictionary of Cell \& Molecular Biology. London: Elsevier: Academic Press.

Lopac, V. 2012. „Interdisciplinarni projekt STRUNA: o nazivlju u prirodnim znanostima“. Kem. Ind. 61, knj. 9-10, 453-454.

Broj 4, prosinac 2018. 
Maxam, A.M., Gilbert, W. 1977. A new method for sequencing DNA. Proc Natl Acad Sci U S A, 74:560-564.

Mendel, G. 1866. Versuche Über Pflanzen-Hybride". Verhandlungen des naturforschenden Vereines zu Brünn 4 (1865), 3-47.

Sanger, F., Nicklen, S., Coulson, A.R. 1977. DNA sequencing with chain-terminating inhibitors. Proc Natl Acad Sci U S A, 74,5463-5467.

Sutton, W.S. 1902. On the morphology of the chromosome group in. Brachystola magna. Biological Bulletin, 4,24-39.

Šulek, B. 1874-1875. Pretisak: 1990. Hrvatsko-njemačko-talijanski rječnik znanstvenoga nazivlja -Deutsch-kroatische wissenschaftliche Terminologie - Terminologia scientifica italiano-croata. Zagreb: Nakladni zavod Globus.

Venter, J. C., Adams, M. D., Myers, E. W., Li, P. W., Mural, R. J., Sutton, G. G., ... \& Gocayne, J. D. 2001. The sequence of the human genome. science, 291(5507), 1304-1351.

Watson, J.D., Crick F.H. 1953. Molecular structure of nucleic acids; a structure for deoxyribose nucleic acid. Nature, 171,737738. 


\title{
Croatian vocabulary of molecular and cell biology
}

\author{
Petra Korać ${ }^{1}$, Ana Vraneša ${ }^{2}$, Bernardina Petrovićí ${ }^{3}$, Mirjana Pavlica ${ }^{1}$ \\ ${ }^{1}$ Division of Molecular Biology, Department of Biology, Faculty of Science, University of Zagreb, Horvatovac $102 a, 10000$ \\ Zagreb, Croatia \\ mirjana.pavlica@biol.pmf.hr \\ 2 Ministry of Culture, Runjaninova 2, 10000 Zagreb, Croatia \\ ${ }^{3}$ Division for Croatian Standard Language, Department for Croatian language, Faculty of Humanities and Social Sciences, \\ University of Zagreb, Ivana Lučića 3, 10000 Zagreb, Croatia
}

\begin{abstract}
The technical vocabulary of many areas is often developed independently of the rules of the Croatian language, especially in the case of young sciences that are developed in English. One such example is the vocabulary of molecular biology. The development of this research area in Croatia began in the 1960s at the University of Zagreb and the Institute Ruđer Bošković. In 1981 Molecular Biology study program started at the Department of Biology at the Faculty of Science, and in 1989 Divison of Molecular Biology at the same Department was founded. However, until recently there was no systematically elaborated development of professional vocabulary of this scientific area. Due to growing significance of the research results from molecular biology and genetics in the context of everyday life at the Department of Molecular Biology two projects were conducted. The first is a translation of the Dictionary of Molecular and Cell Biology that contains more than 12000 entries, whose purpose is to make the professional vocabulary as result of cooperation between linguists and biologists. The second project - "Genetikon" - has been funded by the Croatian Science Foundation through the "Struna" project, and it covers genetic lexicon, enabling the most important concepts and systematically developed Croatian terminology to be gathered at one place. In this paper we give a short overview of the molecular biology vocabulary development with special emphasis on the six basic guidelines that we hope will contribute to the development of the technical vocabulary of genetics and cellular and molecular biology.
\end{abstract}

Keywords: technical vocabulary; vocabulary of molecular biology, genetic lexicon; linguistic-biological cooperation; systematically developed Croatian terminology

Broj 4, prosinac 2018. 